\title{
PERSEPSI MAHASISWA AKUNTANSI: DETERMINAN YANG MEMPENGARUHI PILIHAN KARIR SEBAGAI AUDITOR
}

\author{
Maria Suryaningsih ${ }^{1}$ \\ STIE Muhammadiyah Jakarta, mariasuryaningsih@yahoo.co.id
}

\begin{abstract}
ABSTRAK
Penelitian ini bertujuan untuk menginvestigasi persepsi mahasiswa akuntansi terkait dengan permasalahan orientasi etis auditor, lingkungan kerja auditor dan juga berbagai skandal auditor yang melibatkan auditor. Lebih lanjut, penelitian ini menguji dan menganalisis pengaruh orientasi etis auditor, pengaruh lingkungan kerja dan pengaruh skandal auditor yang mencangkup pengetahuan mengenai skandal audit umum PT KAI terhadap penilaian mereka mengenai pilihan karir sebagai auditor. Penelitian ini dilakukan dengan teknik random sampling di dalam pengumpulan data. Populasi dalam penelitian ini adalah mahasiswa akuntansi Perguruan Tinggi Muhammadiyah program studi Akuntansi di Jakarta yang telah maupun sedang mengambil mata kuliah auditing. Data yang digunakan adalah data primer yang diperoleh melalui kuesioner. Pengujian hipotesis dengan menggunakan regresi sederhana dan regresi berganda. Penelitian ini memuat empat hipotesis. Dari empat hipotesis yang diajukan, semua hipotesis di terima. Hasil pengujian hipotesis ini menunjukkan bahwa orientasi etis, lingkungan kerja auditor dan skandal auditor memiliki nilai signifikan memiliki pengaruh secara bersama/simultan dan signifikan terhadap pilihan karir mahasiswa akuntansi sebagai auditor.
\end{abstract}

Kata Kunci: Orientasi etis auditor, lingkungan kerja auditor, skandal auditor, pilihan karir sebagai auditor,persepsi

\begin{abstract}
The purpose of this study is to investigate the accounting university students' perception about the auditors' ethical orientation, the auditors' working atmosphere and the auditors' scandals. The study is also to examine and to analyze the influence of the auditors' ethical orientation, the auditors' working atmosphere and of the auditors' scandals which encompasses the knowledge of general audit at the state-run Indonesian Railway Company (PT KAI) to the assessment of the career choice as an auditor. This study is conducted with the random sampling technique in the data collection. The accounting students of Muhammadiyah University who have studied the auditing or who are still studying the auditing become the population of this study. The data used in this study is the primary data obtained with questionnaires. Meanwhile, the hypothesis test is using the simple regression and multiple regression. There are four hypotheses in this study, all of which are accepted. The result of the test of this hypothesis shows that the ethical orientation, The working atmosphere, and auditors' scandal, has a significant value of 0,000 The meaning that it has a significant influence to the accounting students' career choice as an auditor. Andthe results ofthis studyhave theabilityconclusionofall theindependent variables of $76.3 \%$ affectthe dependent variableisthe student's career choiceasauditor.
\end{abstract}

Keywords: auditors' ethical orientation, auditors' working atmosphere, auditors' scandal, career choice as an auditor, perception 


\section{PENDAHULUAN}

Perkembangan zaman akan menuntut kelulusan yang lebih berkualitas, mahasiswa dituntut memiliki kemampuan (Skill) dan pengetahuan (knowledge) yang lebih dalam di dunia kerja. Kemampuan dan pengetahuan yang dibutuhkan juga bergantung pada karier atau profesi yang akan dipilih, salah satu karier yang membutuhkan kemampuan dari pengetahuan lebih tersebut adalah karier di bidang akuntansi.

Mahasiswa akuntansi menghadapi berbagai pertimbangan dalam memilih jenis karir yang akan dijalaninya. Pada umumnya, keinginan mereka adalah menjadi seorang profesional di bidang akuntansi. Untuk karir sebagai auditor, terdapat empat bidang pekerjaan yang dapat digeluti oleh lulusan akuntansi yaitu menjadi akuntan public (auditor), akuntan perusahaan, akuntan pemerintah, atau akuntan pendidik. Beragamnya pilihan dalam karir tersebut membuat mahasiswa sulit mengambil keputusan dalam memilih. Hal ini akan menimbulkan pertanyaan mengenai pertimbangan apa yang mendasari pemilihan karir tersebut serta hal-hal apa yang diharapkan oleh mahasiswa akuntansi terhadap pilihannya itu.

Profesi auditor dipandang memiliki prospek yang cerah karena profesi ini memberikan tantangan intelektual dan pengalaman belajar yang tidak ternilai. Selain itu, profesi ini juga memberikan peluang untuk mendapatkan pekerjaan yang menantang dan bervariasi karena dapat ditugaskan di beberapa tempat dan di berbagai perusahaan yang memiliki ciri dan kondisi yang berbeda.

Berbagai informasi yang diperoleh mahasiswa akuntansi mengenai profesi auditor merupakan hal yang penting dalam proses pengambilan keputusan karirnya sebagai auditor. Adanya informasi negatif mengenai orientasi etis auditor, lingkungan kerja auditor dan skandal auditor mungkin dapat mengurangi minat mereka untuk memilih karir sebagai auditor dan mengalihkan pilihan karirnya ke profesi akuntansi yang lain. Dengan demikian, profesi auditor dapat kehilangan calon-calon auditor yang berkualitas.

Dengan adanya serangkaian permasalahan yang terjadi, mulai dari lingkungan kerja auditor hingga berbagai skandal yang terjadi akan menyebabkan berbagai persepsi yang berbeda pada setiap orang. Hal ini terutama berpengaruh besar terhadap mahasiswa akuntansi dalam rangka mengambil keputusan dalam memilih kariernya.

Penelitian yang akan diteliti oleh penulis sebelumnya telah diteliti oleh beberapa peneliti dan penelitian yang akan diteliti ini merupakan pengembangan dari penelitian sebelumnya, sebagai berikut yaitu:

Sharon Ayumediaz (2005) mengenai persepsi mahasiswa akuntansi Universitas Padjajaran tentang lingkungan kerja auditor menunjukkan bahwa mahasiswa akuntansi memiliki persepsi positif tentang lingkungan kerja auditor cenderung memilih auditor sebagai pilihan karirnya yaitu sebanyak $62 \%$ dari total responden. Sedangkan sisanya sebanyak $38 \%$ memilih karir non auditor sebagai pilihan karir.

Penelitian serupa dilakukan oleh Bayu Nugroho (2008) dengan judul Faktor-Faktor yang Mempengaruhi Penilaian Mahasiswa Akuntansi atas Tindakan Auditor dan Corporate Manager dalam Skandal Keuangan serta Tingkat Ketertarikan Belajar dan Berkarir di Bidang Akuntansi. Metode analisis dalam penelitian ini menggunakan regresi berganda. Nugroho (2008) mengatakan bahwa permasalahan yang dianalisis dalam penelitian ini yang pertama pengaruh orientasi etika, gender, dan pengetahuan tentang profesi dan skandal keuangan mahasiswa akuntansi terhadap penilaian mereka mengenai tindakan corporate manager dan auditor; yang kedua adalah pengaruh orientasi etika, gender, umur dan pengetahuan tentang profesi dan skandal keuangan mahasiswa akuntansi terhadap tingkat ketertarikan belajar akuntansi dan bekerja di Kantor Akuntan Publik (KAP). Hasil dari penelitian menunjukkan bahwa orientasi etika (idealisme dan relativisme) tidak ada pengaruh yang signifikan terhadap opini mahasiswa akuntansi atas tindakan auditor dan corporate manager dalam skandal keuangan, ketertarikan mahasiswa akuntansi untuk belajar akuntansi, serta ketertarikan mahasiswa akuntansi untuk bekerja di KAP. Sedangkan, tingkat pengetahuan mengenai profesi akuntansi dan skandal keuangan mahasiswa akuntansi tidak mempengaruhi opini mereka atas tindakan auditor dan corporate manager dalam skandal 
keuangan, ketertarikan mahasiswa akuntansi untuk belajar akuntansi, serta ketertarikan mahasiswa akuntansi untuk bekerja di KAP.

Penelitian ini juga dilakukan oleh Muammar Qaddafi pada tahun 2010, objek penelitiannya adalah mahasiswa akuntansi pada 3 universitas di Makassar yaitu UNHAS, UMI. Dan STIEM Bongaya. Hasil penelitian menunjukkan bahwa persepsi mahasiswa akuntansi pada ketiga universitas tersebut positif terhadap lingkungan kerja auditor dan mereka cenderung akan memilih auditor sebagai pilihan karirnya jika lulus nanti. Sedangkan hasil pengujian hipotesisnya adalah " terdapat pengaruh yang signifikan Persepsi Mahasiswa Akuntansi Mengenai Lingkungan kerja Auditor Terhadap Pilihan Karirnya Sebagai Auditor " terbukti dapat diterima.

Arif Budi Satrio (2012) Dengan penelitiannya Persepsi Mahasiswa Akuntansi mengenai lingkungan kerja dan skandal Auditor Terhadap pilihan karier Sebagai Auditor. (Studi Kasus Pada Program studi Akuntansi Perguruan Tinggi di Swasta di Pontianak). Tujuan penelitian ini adalah untuk menginvestigasi persepsi mahasiswa terkait dengan lingkungan kerja lingkungan kerja yang mencakup (1) job duties and responsibilities, (2) advancement, training and supervision, (3) personal concern dan skandal auditor terhadap opini mereka mengenai akuntan, ketertarikan pada pekerjaan di bidang akuntansi dan pilihan karier mereka sebagai auditor. Kesimpulan yang dapat ditarik dalam penelitian ini adalah pertama, lingkungan kerja tidak mempengaruhi opini mahasiswa akuntansi mengenai akuntan dan ketertarikan mereka pada pekerjaan di bidang akuntansi. Namun demikian, lingkungan kerja mempengaruhi ketertarikan mahasiswa akuntansi pada profesi auditor. Kedua, skandal auditor tidak mempengaruhi opini mahasiswa akuntansi mengenai akuntan, ketertarikan karier mahasiswa akuntansi terhadap pekerjaan di bidang akuntansi, dan ketertarikan mereka pada profesi auditor. Ketiga, lingkungan kerja dan skandal auditor tidak mempengaruhi pilihan karier mahasiswa akuntansi pada profesi auditor.

Berdasarkan fenomena dan penelitian-penelitian sebelumnya yang telah diuraikan diatas, penulis tertarik untuk melakukan penelitian di Perguruan Tinggi Yang menerapkan nilai-nilai islam dan prinsip islam. Selain itu, penulis ingin mengetahui bagaimana persepsi mahasiswa akuntansi mengenai pengaruh orientasi etis Auditor, Lingkungan kerja auditor dan skandal auditor terhadap Pilihan karir sebagai auditor, dan peneliti menemukan ada inkonsisten dari peneliti terdahulu, maka yang selanjutnya peneliti merumuskan kedalam sebuah penelitian yang berjudul "Persepsi Mahasiswa Akuntansi: Determinan Yang Mempengaruhi Pilihan Karir Sebagai Auditor"

Alasan mengapa penelitian ini menarik untuk diteliti kembali adalah karena untuk melihat dan membandingkan faktor - faktor seperti orientasi etis auditor, lingkungan kerja auditor dan skandal auditor yang mempengaruhi pilihan karir seorang mahasiswa sebagai auditor dengan responden dari lokasi, kultur yang berbeda dan juga menggunakan prinsip dan nilai nilai yang berbeda yaitu Islam.

Berdasarkan latar belakang dan identifikasi masalah di atas, maka yang menjadi masalah dalam penelitian ini adalah:

1. Apakah Orientasi etis auditor berpengaruh secara positif atau negatif secara signifikan terhadap pilihan karir mahasiswa akuntansi sebagai auditor?

2. Apakah Lingkungan kerja auditor berpengaruh secara positif atau negatif secara signifikan terhadap pilihan karir mahasiswa akuntansi sebagai auditor?

3. Apakah Skandal auditor berpengaruh secara positif atau negatif secara signifikan terhadap pilihan karir mahasiswa akuntansi sebagai auditor?

4. Apakah Orientasi Etis auditor, Lingkungan kerja auditor dan Skandal auditor bersamasama berpengaruh secara positif atau negatif secara signifikan terhadap pilihan karir mahasiswa akuntansi sebagai auditor?

Berdasarkan rumusan masalah di atas maka tujuan dari penelitian ini adalah:

1. Untuk menguji dan menganalisis pengaruh orientasi etis auditor terhadap pilihan karir mahasiswa akuntansi sebagai auditor .

2. Untuk menguji dan menganalisis pengaruh lingkungan kerja auditor terhadap pilihan karir mahasiswa akuntansi sebagai auditor . 
3. Untuk menguji dan menganalisis pengaruh skandal auditor terhadap pilihan karir mahasiswa akuntansi sebagai auditor.

4. Untuk menguji dan menganalisis pengaruh orientasi etis auditor, lingkungan kerja auditor dan skandal auditor secara bersamaan dapat mempengaruhi pilihan karir mahasiswa akuntansi sebagai auditor.

\section{KAJIAN LITERATUR}

\section{Karier}

Karier Menurut Handoko $(2001,123)$ "Suatu karier adalah seluruh pekerjaan (jabatan) yang ditangani atau dipegang selama kehidupan kerja seseorang. "Selanjutnya menurut Gordon $(2003,83)$ "A career refers to a lifelong sequence of related jobs and experience".

Berdasarkan pengertian karier di atas maka dapat disimpulkan bahwa karier merupakan keseluruhan jabatan atau pekerjaan atau posisi yang dapat diduduki oleh seseorang selama kehidupan kerjanya dalam organisasi atau berbagai organisasi.

Handoko $(2001,123)$ "Perencanaan karier (career planning) adalah proses melalui mana seseorang memilih sasaran karier dan jalur kesasaran tersebut".

\section{Keputusan Pemilihan Karier}

Proses pengambilan keputusan merupakan proses yang melibatkan pemilihan dari berbagai alternatif tindakan. Proses pengambilan keputusan menurut Gitosudarmo dan Sudita (2000, 176-182) meliputi:

1. Menetapkan Tujuan

Dalam pengambilan keputusan harus memiliki tujuan yang akan mengarahkannya, apakah spesifik yang dapat diukur hasilnya maupun sasaran yang bersifat umum. Pada tingkat individu, tujuan ditentukan oleh masing-masing orang sesuai dengan sistem nilai seseorang.

2. Mengidentifikasi Permasalahan

Pengambilan keputusan dimulai pada saat adanya permasalahan yang timbul. Permasalahan terjadi karena adanya ketidaksesuaian antara kenyataan yang terjadi dengan apa yang diharapkan. Apabila permasalahan yang ada dapat diidentifikasi dengan baik maka permasalahan yang ada dapat diselesaikan dengan baik.

3. Mengembangkan Sejumlah Alternatif

Setelah permasalahan diidentifikasikan maka diperlukan pengembangan sejumlah alternatif untuk penyelesaian masalah.pengambilan keputusan yang rasional mengharuskan pengambilan keputusan untuk mengkaji semua alternatif pemecahan masalah yang potensial.

4. Penilaian dan Pemilihan Alternatif

Setelah dilakukan pengembangan alternatif maka kemudian dilakukan evaluasi terhadap masing-masing alternatif yang telah dikembangkan dan dipilih sebuah alternatif yang terbaik. alternatif terbaik berkaitan dengan sasaran atau tujuan yang hendak dicapai.

5. Evaluasi dan Pengendalian

Tindakan koreksi merupakan langkah terakhir yang perlu dilakukan sehubungan dengan pengambilan keputusan. Faktor-faktor yang mempengaruhi terdiri dari penghargaan finansial, pelatihan profesional, nilai-nilai sosial, lingkungan kerja, pertimbangan pasar kerja dan personalitas (Rahayu dkk,2003).

\section{Pengertian Orientasi Etis}

Orientasi Etis didefinisikan oleh Salim (1991) yang dikutip mutmainah (2007) adalah sebagai dasar pemikiran untuk menentukan sikap arah dan sebagainya secara tepat dan benar yang berkaitan dengan dilema etis. idealisme merupakan orientasi etika yang mengacu pada sejauh mana seseorang percaya bahwa konsekuensi dari tindakan yang dilakukan dapat terjadi tanpa melanggar nilai-nilai moral. Relativisme adalah orientasi etika yang mengacu pada penolakan terhadap nilai-nilai (aturan) moral universal yang membimbing perilaku. 


\section{Lingkungan Kerja}

Menurut Sedarmayanti $(2009,21)$ "lingkungan kerja adalah keseluruhan alat perkakas dan bahan yang dihadapi, lingkungan sekitarnya di mana seseorang bekerja, metode kerjanya, serta pengaturan kerjanya baik sebagai perseorangan maupun sebagai kelompok." Menurut DeZoort et al (1997, 282) lingkungan kerja auditor dapat dibagi ke dalam tiga dimensi yang meliputi berbagai isu yang relevan dengan dunia akuntan publik yaitu:

\section{Job duties and responsibilities}

Job duties and responsibilities mencakup pengetahuan dan keahlian yang dibutuhkan oleh seorang auditor dan juga mengenai atribut dan manfaat profesi auditor.keahlian dan kemampuan dalam hal ini harus dimiliki oleh seorang auditor dalam melaksanakan tugasnya.

\section{Advancement, training, dan supervision}

Advancement, training, dan supervision yang mencakup kemahiran dalam pekerjaan, pelatihan, pendidikan yang dilaksanakan oleh Kantor Akuntan Publik, promosi jabatan dan kecukupan supervisi kerja, Advancement, training, dan supervision.

\section{Personal concern}

Personal concern yang mencakup standar etik dan interaksi dengan rekan seprofesi, dukungan perusahaan dalam mengikuti Ujian Sertifikasi Akuntan Publik (USAP).

\section{Skandal Auditor}

Skandal merupakan insiden yang dipublikasikan yang melibatkan dugaan pelanggaran, aib, atau pencabulan moral. berkaitan dengan skandal, standar pengauditan menyatakan bahwa faktor yang membedakan kecurangan dan kekeliruan adalah apakah tindakan yang mendasarinya sehingga berakibat terjadinya salah saji dalam laporan keuangan, yang berupa tindakan yang baik disengaja maupun tidak disengaja. Skandal pengauditan ini menjadi acuan untuk menentukan apakah kasus-kasus yang melibatkan auditor merupakan suatu kecurangan ataukah hanya dikarenakan kekeliruan yang tidak disengaja.

\section{Kerangka Pemikiran}

\section{Gambar 1}

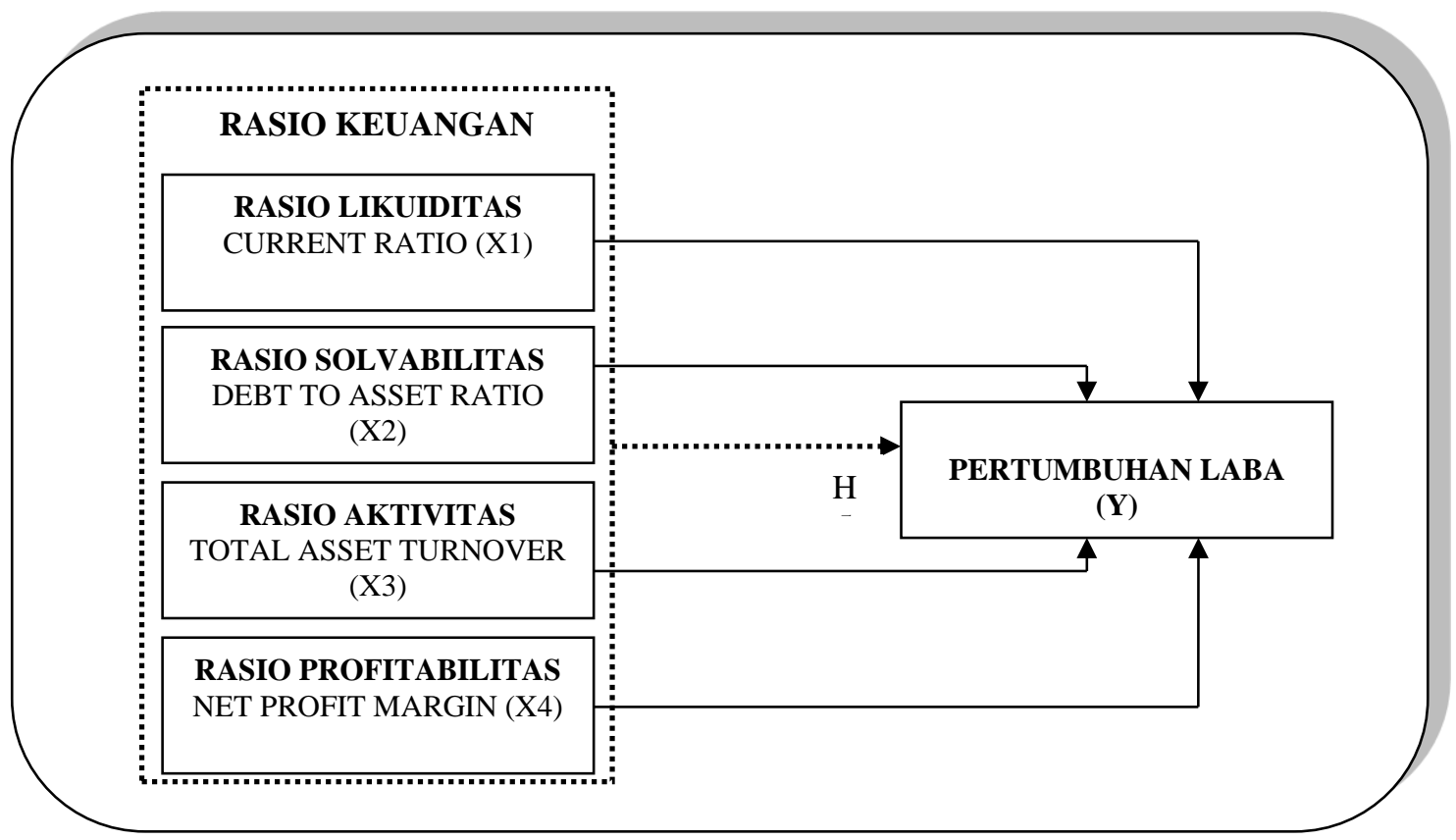




\section{Keterangan:}

H1: Pengaruh orientasi etis auditor terhadap pilihan karir sebagai auditor?

H2: Pengaruh lingkungan kerja auditor terhadap pilihan karir sebagai auditor?

H3: Pengaruh skandal auditor terhadap pilihan karir sebagai auditor?

H4: Pengaruh orientasi etis auditor, lingkungan kerja auditor dan skandal auditor secara bersamaan terhadap Pilihan Karir sebagai auditor?

\section{Hipotesis}

Hipotesis dalam penelitian ini adalah:

a. $\mathrm{H} 1$ = Adanya pengaruh positif dan berpengaruh signifikan mengenai Orientasi Etis auditor terhadap pilihan karier sebagai auditor.

b. $\mathrm{H} 2$ = Adanya pengaruh positif dan berpengaruh secara signifikan mengenai lingkungan kerja auditor terhadap pilihan karier sebagai auditor.

c. $\mathrm{H} 3=$ Adanya pengaruh positif dan berpengaruh secara signifikan mengenai skandal auditor terhadap pilihan karier sebagai auditor.

d. H4 = Adanya Pengaruh Orientasi Etis auditor, Lingkungan kerja auditor dan Skandal Auditor secara bersama-sama/simultan terhadap pilihan karier sebagai Auditor.

\section{METODE PENELITIAN}

Penelitian ini menggunakan data primer. Menurut Hermawan $(2009,168)$ "Data primer merupakan data yang dikumpulkan secara langsung oleh peneliti untuk menjawab masalah atau tujuan penelitian yang dilakukan dalam penelitian eksploratif, deskriptif maupun kausal dengan menggunakan metode pengumpulan data berupa survei ataupun observasi." Data primer ini diperoleh melalui studi lapangan dengan menggunakan kuesioner yang terdiri dari beberapa item pertanyaan.

\section{Populasi dan Sampel Penelitian}

Populasi dari penelitian ini adalah seluruh mahasiswa program studi akuntansi pada Sekolah Tinggi Ilmu Ekonomi Muhammadiyah Jakarta baik Kampus Kramat dan juga Kampus Minangkabau, Universitas Prof. Dr. Hamka (UHAMKA), dan STIE Ahmad Dahlan. Perguruan tinggi ekonomi muhammadiyah di Jakarta dipilih sebagai tempat penelitian karena merupakan perguruan tinggi islam yang mahasiswanya diwajibkan menempuh mata kuliah.

Telah disampaikan dalam batasan masalah, sampel penelitian yang diambil adalah mahasiswa aktif program studi akuntansi reguler dan pindahan tahun akademik 2011 dan 2012.

Tabel 1: Jumlah Pupulasi

Sumber PDPT Forlap Dikti 2014

\begin{tabular}{|c|c|c|c|c|c|c|}
\hline \multirow[b]{2}{*}{$\mathbf{O}$} & \multirow{2}{*}{$\begin{array}{l}\text { NamaPerguruan } \\
\text { Tinggi }\end{array}$} & \multirow{2}{*}{$\begin{array}{l}\text { Lembag } \\
\text { a }\end{array}$} & $011 / 1^{2}$ & $011 / 2^{2}$ & $012 / 1^{2}$ & $012 / 2^{2}$ \\
\hline & & & OTAL $^{\mathrm{T}}$ & OTAL $^{T}$ & ${ }_{\text {OTAL }}^{T}$ & ${ }_{\text {OTAL }}^{T}$ \\
\hline & $\begin{array}{l}\text { STIE Ahmad } \\
\text { Dahlan }\end{array}$ & $\begin{array}{l}\text { Akuntan } \\
\text { si S1 }\end{array}$ & $60^{4}$ & $31^{4}$ & $4^{6}$ & $88^{5}$ \\
\hline & $\begin{array}{c}\text { STIE } \\
\text { Muhammadiyah Jakarta } \\
\end{array}$ & $\begin{array}{l}\text { Akuntan } \\
\text { si S1 }\end{array}$ & $40^{2}$ & $70^{2}$ & $02^{3}$ & $29^{3}$ \\
\hline & $\begin{array}{l}\text { UniversitasProf.D } \\
\text { r. Hamka (UHAMKA) }\end{array}$ & $\begin{array}{l}\text { Akuntan } \\
\text { si S1 }\end{array}$ & $25^{5}$ & $65^{4}$ & $34^{6}$ & $38^{5}$ \\
\hline
\end{tabular}




\section{Sampel}

Pengumpulan sampel pada penelitian ini menggunakan random sampling yaitu pengambilan anggota sampel dilakukan secara acak tanpa memperhatikan strata yang ada dalam populasi tersebut (Sugiyono, 2011:82). Dan sampel yang digunakan peneliti berjumlah 315 mahasiswa. Jumlah sampel ini ditentukan dengan rumus Slovin (Umar, 2004:108):

$$
n=\frac{N}{1+N e^{2}}
$$

Keterangan :

n: Ukuran sampel

$\mathrm{N}$ : Ukuran populasi

e: Presentase kelonggaran ketidaktelitian karena kesalahan pengambilan sampel yang masih dapat ditolerir

$\frac{1455}{1+1455(0,05)^{2}}$

Jumlah sampel dalam penelitian ini dengan jumlah populasi sebanyak 1455 mahasiswa Mahasiswa dan tingkat kesalahan sebesar 5\% adalah sebagai berikut:

$$
\begin{aligned}
& \mathrm{n}= \\
& \mathrm{n}=314
\end{aligned}
$$

\section{PEMBAHASAN}

Dalam penelitian ini diuji mengenai orientasi etis auditor, pengaruh lingkungan kerja yang mencakup (1) job duties and responsibilities, (2) advancement, training and supervision, (3) personal concern dan skandal auditor terhadap penilaian mahasiswa akuntansi mengenai pilihan karir sebagai auditor. Berdasarkan hasil pengujian empiris yang telah dilakukan terhadap beberapa hipotesis dalam penelitian ini maka sebagaian besar menunjukkan hasil yang berpengaruh signifikan terhadap penilaian mereka terhadap pilihan karier mereka sebagai auditor. Hasil pengujian regresi berganda dapat ditunjukkan sebagai berikut:

\begin{tabular}{|c|c|c|c|c|c|c|}
\hline & \multirow[t]{2}{*}{ Model } & \multicolumn{2}{|c|}{$\begin{array}{l}\text { Unstandardized } \\
\text { Coefficients }\end{array}$} & \multirow{2}{*}{$\begin{array}{c}\text { Standardized } \\
\text { Coefficients }\end{array}$} & \multirow[t]{2}{*}{$\mathrm{t}$} & \multirow[t]{2}{*}{ Sig } \\
\hline & & B & $\begin{array}{l}\text { Std. } \\
\text { Error }\end{array}$ & & & \\
\hline \multirow{4}{*}{1} & (Constant) & 6.825 & 1.187 & & 5.752 & .000 \\
\hline & $\mathrm{X} 1$ & .385 & .039 & .400 & 9.904 & .000 \\
\hline & $\mathrm{X} 2$ & .421 & .037 & .482 & 11.435 & .000 \\
\hline & $\mathrm{X} 3$ & .065 & .018 & .111 & 3.524 & .000 \\
\hline
\end{tabular}

\section{Tabel 4.2}

\section{Hasil Uji Signifikansi Orientasi Etis}

\section{Coefficientsa}

a. Dependent Variable: Pilihan KarirAuditor

Sumber: Hasil Kuesioner, diolah dengan SPSS versi 18 


\section{Orientasi Etis Auditor, Lingkungan}

Auditor Lingkungan Kerja dan Skandal Auditor terhadap Pilihan Karier Sebagai Auditor

Persamaan Regresi: $\mathrm{Y}=6.825+0.385 \mathrm{X} 1+0.421 \mathrm{X} 2+0.065 \mathrm{X} 3$

\section{Kerja dan Skandal Auditor}

Pilihan.Karier $=6.825,+0,385$ Orientasi Etis $+0,412$ Lingkungan.Kerja $+0,065$ Skandal Auditor $+\varepsilon$

Dari hasil analisis di atas dapat dilihat bahwa model regresi linear berganda penelitian ini adalah $\mathrm{Y}=6,825+0,385$ Orientasi Etis $(\mathrm{X} 1)+0,412$ Lingkungan Kerja $(\mathrm{X} 2)+0,065$ Skandal Auditor $(\mathrm{X} 3)+\varepsilon$. Koefisien Determinasasi sebesar 0,763 yang memiliki arti bahwa pengaruh variabel orientasi etis auditor (X1), lingkungan kerja (X2) dan skandal auditor (X3) terhadap pilihan karir sebagai auditor(Y) adalah sebesar 76,3\% dan sisanya 23,7 \% dipengaruhi oleh variabel lain di luar model penelitian ini.

Secara keseluruhan hipotesis dengan menggunakan regresi dapat dilihat pada tabel 4.2 berikut ini:

Tabel 2

Ringkasan Hasil Pengujian Hipotesis

\begin{tabular}{|l|l|l|}
\hline Kode & Hipotesis & Hasil \\
\hline H1 & $\begin{array}{l}\text { Orientasi Etis auditor mempengaruhi persepsi mahasiswa } \\
\text { akuntansi terhadap pilihan karir auditor. }\end{array}$ & Diterima \\
\hline H2 & $\begin{array}{l}\text { Lingkungan kerja auditor mempengaruhi persepsi } \\
\text { mahasiswa akuntansi terhadap pilihan karir auditor. }\end{array}$ & Diterima \\
\hline H3 & $\begin{array}{l}\text { Skandal auditor mempengaruhi pilihan karier mahasiswa } \\
\text { akuntansi untuk bekerja sebagai auditor. }\end{array}$ & Diterima \\
\hline H4 & $\begin{array}{l}\text { Orientasi Etis auditor, Lingkungan kerja dan skandal } \\
\text { auditor secara bersama sama/ simultan mempengaruhi } \\
\text { pilihan karier mahasiswa akuntansi sebagai auditor. }\end{array}$ & Diterima \\
\hline
\end{tabular}

Sumber: Data Primer, 2014

\section{PENUTUP}

Berdasarkan hasil penelitian dan pembahasan yang telah dilakukan sebelumnya, maka untuk menjawab permasalahan yang ada dalam penelitian ini penulis menarik kesimpulan sebagai berikut:

1. Pengaruh Orientasi Etis Auditor Mengenai Pilihan Karier Mahaiswa sebagai auditor.Variabel Pengaruh Orientasi Etis Auditor yang mencakup kepribadian, Dinamisme dan relativisme memiliki nilai signifikan 0,000 yang lebih kecil dari 0,05 yang memiliki arti variabel pengaruh orientasi etis auditor tersebut memiliki pengaruh signifikan terhadap pilihan karir mahasiwa akuntansi sebagai auditor.

2. Lingkungan Kerja Terhadap Pilihan Karir Mahasiswa Sebagai auditor.

Variabel lingkungan kerja auditor yang mencakup (1) job duties and responsibilities, (2) advancement, training and supervision, (3) personal concern memiliki nilai signifikan 0,000 yang lebih kecil dari 0,05 yang memiliki arti bahwa variabel pengaruh lingkungan kerja memiliki pengaruh signifikan terhadap pilihan karier mahasiswa akuntansi sebagai auditor. 
3. Pengaruh Skandal Auditor Terhadap Pilihan Karier mahasiswa akuntansi sebagai Auditor. Variabel skandal auditor memiliki pengaruh signifikan terhadap pilihan karier mahasiswa akuntansi sebagai auditor, karena nilai signifikannya 0,000 lebih kecil dari 0,05 .

4. Pengaruh Orientasi Etis Auditor, Lingkungan Kerja dan Skandal Auditor Terhadap Pilihan Karier Sebagai Auditor. Pengaruh Orientasi Etis Auditor, Lingkungan kerja dan Skandal Auditor memiliki pengaruh secara simultan/bersamaan yang signifikan terhadap pilihan karir mahasiswa akuntansi sebagai auditor, yang memiliki nilai signifikan 0,000 lebih kecil dari 0,05. Orientasi Etis Auditor, Lingkungan kerja dan Skandal Auditor memiliki pengaruh positif secara simultan yang signifikan terhadap pilihan karir mahasiswa akuntansi sebagai auditor dengan kemampuan mempengaruhi sebesar 76,3 persen mempunyai arti ada faktor lain yang mempengaruhi pilihan karier mahasiswa akuntansi sebagai auditor sebesar $23,7 \%$.

\section{REFERENSI}

Adji Suratman, 2010, Materi Kuliah Good Corporate Governance Program Maksi STIE Y.A.I, PT. Tintamas Indonesia.

Agoes, Sukrisno dan Ardana I Cenik, 2009, Etika Bisnis dan Profesi Tantangan Membangun Manusia Seutuhnya, Jakarta: Salemba Empat.

Alim, M. Nizarul, Trisni Hapsari, dan Liliek Purwanti, 2007, Pengaruh Kompetensi dan Independensi Terhadap Kualitas Audit dengan Etika Auditor Sebagai Variabel Moderasi, Simposium Nasional Akuntansi X Makasar, 26-28 Juli, pp. 1-26

Arens, Alvin A., Randal J. Elder dan Mark S. Beasley, 2008 a terj. Auditing dan Jasa Assurance: Pendekatan Terintegrasi, oleh Herman Wibowo, edisi ke-12, Jilid 1, Jakarta: Penerbit Erlangga

Arens, Alvin A., Randal J. Elder dan Mark S. Beasley, 2008 , terj. Auditing dan Jasa Assurance: Pendekatan Terintegrasi, oleh Gina Gania, edisi ke-12, Jilid 2, Jakarta: Penerbit Erlangga

AAOFI. (1998) Accounting and Auditing Standards for Islamic Financial Institution, state of Bahrain. www.aaoifi.com

Chan, Andi Setiawan, Januari 2012, Analisis Faktor-faktor Yang Mempengaruhi Pemilihan Karir Menjadi Akuntan Publik Oleh Mahasiswa Jurusan Akuntansi. Jurnal Ilmiah Mahasiswa Akuntansi. Vol 1, No.1

Comunale, Christie L., Thomas R. Sexton, dan Stephen C. Gara, 2006, Professional Ethical Crises A Case Study of Accounting Majors, Managerial Auditing Journal, Vol. 21 No. 6, pp. 636-656

DeZoort, F.T., A.T. Lord, dan B.R. Cargile, 1997, A Comparison of Accounting Professors' and Student Perceptions of the Public Accounting Work Environment, Accounting Education (Fall), pp 281-298

Efferin, Sujoko, Stevanus Hadi Darmadji, dan Yuliawati Tan, 2008, Metode Penelitian Akuntansi: Mengungkap Fenomena dengan Pendekatan Kuantitatif dan Kualitatif, Yogyakarta: Graha Ilmu.

Fahrianta, Riswan Yudhi dan Akhmad Yafiz Syam, 2011, Perbandingan Sensitivitas Etis Antara Mahasiswa Akuntansi dan Mahasiswa Akuntansi Wanita serta Mahasiswa Akutnansi dan Mahasiswa Bisnis Non Akuntansi, Jurnal Manajemen dan Akuntansi, Vol. 12, April, pp. 79-90

Ghani, Erlane K., Jamaliah Said dan Noraini Mohd Nasir, 2008, The $21^{S T}$ Century Accounting Career from the Perspective of the Malaysian University Students, Asian Social Science, Vol. 4 No. 8, August, pp. 73-83 
Heiat, Abbas, Doug Brown, dan Debra M. Johnson, 2007, An Empirical Analysis Of Underlying factors Affecting The Choice Of Accounting Major, Journal of College Teaching \& Learning, Vol. 4 No. 8, August, pp. 83-98

Hermawan, Asep, 2009, Penelitian Bisnis: Paradigma Kuantitatif, Jakarta: PT Grasindo

Jatmika, Windy, 2011, Pengaruh Tekanan Anggaran Waktu, Kepatuhan Kode Etik dan Pengendalian Mutu KAP terhadap Kualitas Audit, Jurnal Ekonomi, Volume 2 Nomor 1, Gresik: Fakultas Ekonomi Universitas Muhammadiyah Gresik

Koroy, Tri Ramaraya, 2008, Pendeteksian Kecurangan (Fraud) Laporan Keuangan oleh Auditor Eksternal, Jurnal Akuntansi dan Keuangan, STIE Nasional Banjarmasin, Vol 10 No. 1 pp 22-33

Kode Etik Profesi Akuntan Islam. 7 Nov 2012, akses di http://supriakuntansisy.blogspot.com/2011/04/kode-etik-profesi-akuntan-islam.html

Kurnia, 2006, Perbedaan Persepsi tentang Karier di Kantor Akuntan Publik Antara Mahasiswa dan Staf Kantor Akuntan Publik, Jurnal STIESIA Surabaya, Ekuitas Vol. 13 No.2, pp 199-218

Leiwakabessy, Audry, 2009, Pengaruh Orientasi Etis Dan Budaya Jawa Terhadap Prilaku Etis Auditor, Semarang : Program Studi Magister Sains Akuntansi Program Pasca Sarjana Universitas Diponegoro

Ludigdo, Unti, 2006, Strukturisasi Praktik Etika di Kantor Akuntan Publik: Sebuah Studi Interpretif, Simposium Nasional Akuntansi Padang, Agustus, pp. 1-22

Mahmud, Amir, 2008, Persepsi Mahasiswa Akuntansi Mengenai Penyusunan Laporan Keuangan, Lembaran Ilmu Kependidikan Jilid 37 No. 2, Desember, pp. 100-106

Martadi, Indriana Farid dan Sri Suranta, 2006, Persepsi Akuntan, Mahasiswa Akuntansi, dan Karyawan Bagian Akuntansi Dipandang dari Segi Gender Terhadap Etika Bisnis dan Etika Profesi (Studi di Wilayah Surakarta), Simposium Nasional Akuntansi 9 Padang, pp. $1-25$

Mulyadi, 2002, Auditing, edisi ke-6, Jakarta: PT Salemba Empat

Nugroho, Bayu, 2008 ,Faktor-Faktor Yang Mempengaruhi Penilaian Mahasiswa Akuntansi Atas Tindakan Auditor dan Corporate Manager Dalam Skandal Keuangan Serta Tingkat Ketertarikan Belajar Dan Berkarir di Bidang Akuntansi, Semarang : Program Studi Magister Sains Akuntansi Program Pasca Sarjana Universitas Diponegoro.

Nurlaela Wati, Lela, 2014, Aplikasi Komputer Statistika, Jakarta.

Priyatno, Dwi, 2008, Mandiri Belajar SPSS (Statistical Product and Service Solution) untuk Analisis Data dan Uji Statistik: Bagi Mahasiswa dan Umum, Yogyakarta: MediaKom.

Robbins, Stephen P, 2003, terj., Perilaku Organisasi, oleh Tim Indeks, Jilid 1, Jakarta: PT Indeks Kelompok Gramedia.

Satrio, Arif Budi, 2012, Persepsi Mahasiswa Akuntansi Mengenai Lingkungan Kerja dan Skandal Auditor Terhadap Pilihan Karier Sebagai Auditor: studi pada program studi akuntansi Perguruan Tinggi Swasta di Pontianak, Jakarta: Program Pascasarjana STIE Y.A.I

Sedarmayanti, 2001, Sumber Daya Manusia dan Produktivitas Kerja, Bandung: Mandar Maju.

Sekolah Tingi Ilmu Ekonomi Y.A.I, 2010, Buku Pedoman Penulisan Tesis, Jakarta, Sekolah Tinggi Ilmu Ekonomi Y.A.I

Sugiyono, 2012, Statistika untuk Penelitian, Bandung: CV Alfabeta.

Supranto, 2012, Petunjuk Praktis Penelitian ilmiah untuk menyusun Skripsi, Tesis dan Disertasi, Jakarta : MItra Wacana Media.

Tuanakotta, Theodarus M, 2013, Audit Berbasi ISA. Jakarta: Salemba Empat.

Wirianata, Henny, dan Sofyan S. Harahap, 2007, Persepsi Dosen dan Mahasiswa Akuntansi Terhadap Profesi Akuntan Publik Pasca Enron: Studi Kasus Pada Lima PTS di Jakarta Barat, Media Riset Akuntansi, Auditing dan Informasi, Vol 7 No. 3, Desember, pp. 367393 